\title{
Antiophidian sera sterility control: topics in perspective
}

\author{
Paula Gomes Santos ${ }^{1,2}$, Dilvani Oliveira Santos ${ }^{1,2}$, Lilia Ribeiro Seródio ${ }^{3}$, Rachel de Souza Marinho ${ }^{4}$, \\ Carlos Rangel Rodrigues ${ }^{4}$, Lucio Mendes Cabral ${ }^{4}$, Marcelo de Pádula ${ }^{5}$, Valéria Pereira de Sousa ${ }^{4}$, \\ Helena Carla Castro ${ }^{1,2^{*}}$
}

\begin{abstract}
${ }^{1}$ Department of Cellular and Molecular Biology, Institute of Biology, Federal Fluminense University, ${ }^{2}$ Course of Specialization in Applied Microbiology and Parasitology, Biomedical Institute, Federal Fluminense University, ${ }^{3}$ Department of Viral Vaccine, Vital Brazil Institute, ${ }^{4}$ Department of Medications, Faculty of Pharmacy, Federal University of Rio de Janeiro, ${ }^{5}$ Federal University of Rio de Janeiro, Department of Clinical and Toxicological Analyzes, Faculty of Pharmacy
\end{abstract}

\begin{abstract}
The aim of this work is to review the most important topics about the antiophidic sera sterility, including obtaining methods, sterilization procedures and clean room control using Vital Brazil Institute (VBI) as an example. Bibliographical research was performed through Medline, Lilacs, PubMed, ISI and the Fundação Oswaldo Cruz - RJ and VBI Libraries, from 1960 to 2009. The antiophidic sera for human use are immunobiologic products produced in Brazil by three national laboratories, including VBI. Due to the parenteral use, these products should be sterile and pyrogen-free, which demands the microbiological control during the whole fabrication process. The sterility and pyrogen tests are important steps to ensure the quality and safety of these immunobiological products. Thus, these tests are target for continue evaluation and improvement. The most interfering aspects in the consistency and analytical patterns include the proper method selection, sampling, culture conditions and validation criteria. As the national and international legal requirements are cautious with the assays validation and approval of sterile parenteral products; the intrinsic limitations for established assays still require more investigation aiming the continue improvement of the microorganism and contaminants detection methods and optimization of the analysis extent.
\end{abstract}

Uniterms: Microbiologic control. Antiophidic sera. Sterility test. Contaminants.

O objetivo deste trabalho é revisar os tópicos mais relevantes para o controle da esterilidade de soros antiofídicos, abordando-se métodos de obtenção, procedimentos de esterilização e o controle de áreas limpas utilizando como exemplo os procedimentos adotados pelo Instituto Vital Brazil (IVB). Um levantamento bibliográfico foi realizado no Medline, ISI, Biblioteca da Fundação Oswaldo Cruz-RJ e IVB, no período de 1960 a 2009. Os soros antiofídicos para uso humano são produtos imunobiológicos fabricados no Brasil por três laboratórios nacionais, dentre eles o IVB. Por serem de administração parenteral, devem ser obrigatoriamente estéreis e apirogênicos, exigindo controle microbiológico durante todo o processo de fabricação. O teste de esterilidade e apirogenia são importantes instrumentos para garantir a qualidade e segurança microbiológica desses produtos, sendo alvo de avaliações constantes para seus aprimoramentos. Os aspectos que mais interferem na sua consistência e valor analítico incluem a escolha adequada do método, amostragem, condições de cultivo e critérios de validação. À medida que os requisitos legais nacionais e internacionais se mostram rigorosos na validação de ensaios e aprovação de produtos estéreis parenterais, limitações intrínsecas ao ensaio padronizado requisitam mais investigações, objetivando o aprimoramento contínuo nos métodos de detecção de microorganisms, contaminantes e otimização do tempo total de análise.

Unitermos: Controle microbiológico. Soros antiofídicos. Teste de esterilidade. Contaminantes.

\footnotetext{
*Correspondence: H. C. Castro. Department of Medications, Faculty of Pharmacy, Federal University of Rio de Janeiro, 24020-150 Rio de Janeiro, Brasil. E-mail: hcastrorangel@yahoo.com.br
} 


\section{INTRODUCTION}

Brazil is one of the countries that are pioneers in the treatment of the envenomation caused by snake venom. According to the Brazilian Health Ministry, snakes are responsible for about 20,000 accidents per year with 100 deaths (FUNASA/MS, 1998).

The antiophidic sera used for treating these patients are immunobiological products for subcutaneous or submucous injections use. Among several requirements, these products must be microorganism and endotoxin free, which may be obtained through a rigid microbiologic control during the whole fabrication process (Brasil, 2005; United States Pharmacopeia, 2008)

The general sterility concept refers to total absence of organisms capable of reproduction (Runkle, Phillips, 1969). However, due to the current statistical knowledge about microorganism death, there are some questions about product sterility concepts. The sterility processes follow the criteria of logarithmic reduction of the contaminant amount in the product. Despite of that, it is not possible to assure the complete removal of all forms of contamination.

The most applicable probabilistic concept suggests that the lowest probability of the microbial presence is achieved when it is smaller than $10^{-6}$, which assures the sterility condition of the product. As a consequence, the expression "living form-free" has been used instead of sterile (Bugno, 2001; Luqueta, 2003).

In order to evaluate the analytical significance of the sterility test, it is necessary to understand the intrinsic problems of microbiological detection in the assays as well as the difficulties on sampling, since it should assure the statistical significance in terms of batch size (Pinto, Kanako, Ohara, 2003).

According to the current Pharmacopeia accepted by National Agency of Health Surveillance of Brazil (Brasil, 2003), the sterility condition of a product requires optimal processing conditions under Good Manufacturing Practices (GMP), and absence of microbial growth in appropriate culture media of a statistically significant sample(Brazilian Pharmacopeia, 1988; European Pharmacopoeia, 2007; British Pharmacopoeia, 2008; United States Pharmacopeia, 2008).

The products without evident alterations may also contain microbial contamination. In immunocompetent adults, the contact with contaminated products may not represent a serious problem, unless in case of the: a) microorganism is a primary pathogen, $b$ ) microbial burden is elevated or c) product is for inoculation in areas such as blood vessels, injured skin, mucosa or eyes. The risk is higher when it involves an immunodepressed patient (Denyer, Baird, 2006).

Therefore, the risk of infection depends on factors such as qualitative and quantitative characteristics of the microorganisms, host resistance and administration root. In general, the presence of non-pathogenic microorganism is allowed for products of oral or topic use in a limited amount, if the resistance is maintained inside the validity period (Hinrichsen, 2004). Differently, for the parenteral products, such as antiophidic sera, the risk of infection must be strictly controlled concerning the contaminant presence by using sterility and endotoxin detection tests.

Due to the importance of the microbiological control in the antiophidic sera production process and its influence in these products quality evaluation, the aim of this review is to identify the most important aspects of manufacturing and controlling living form-free products through GMP. On that purpose we searched specialized bibliographies and legal sources (legislations and Pharmacopeia) also approaching concepts about parametric release proposed by ANVISA in courses and routine inspections.

\section{Sterile parenteral solution manufacturing}

The manufacturing of sterile liquid products is divided into three groups, including those submitted to $(i)$ final sterilization (the product is already in the primary flask) by using thermal (autoclave or dry heat), chemical (ethylene oxide) or irradiation methods; (ii) aseptic manipulation; and (iii) proper filtration process as a sterilizing step. In the last two groups, the product is exposed to potential contamination sources at the end of the process (Brazilian Pharmacopeia, 1988).

In pharmaceutical industry, the final sterilization process is always a selective procedure, especially the use of autoclavation, in which the compatibility between the nature of the product and the sterilizing agent should be confirmed (Hinrichsen, 2004).

The microbiological contamination or bioburden of a sterile medicament production must be sufficiently reduced ( $\sim 100 \mathrm{UFC} / \mathrm{mL}$ or $\mathrm{g})$ prior to the sterilization process to reduce the endotoxins formation, especially pyrogens. In a manufacturing process, all solutions must be submitted to a sterilizing filtration prior to the filling process and sterilization in their final recipients, preferentially by using wet heat if the carried drug is thermal-resistant. The wet heat sterilization led to the coagulation and denaturation of microorganisms essential proteins and enzymes. The autoclavation is an effective and safe wet heat sterilization procedure and the most used sterilization method in the industry (Hinrichsen, 2004; Trabulsi, Alterthum, 2005; 
Brazilian Pharmacopeia, 1988; European Pharmacopoeia, 2007; British Pharmacopoeia, 2008; United States Pharmacopeia, 2008).

As some pharmaceutical formulations may not be sterilized in its final recipient, they must be submitted to a sterilization filtering process or to an aseptic manipulation. The sterilizing filtration aims to physically remove microorganisms, particulate gas and liquid materials, excluding bigger particles or adsorpting particles smaller than the filter pore $(0.22$ to $0.10 \mu \mathrm{m})$. Different filtering materials are commercialized such as polycarbonate or cellulose derived (nitrate and acetate) matrixes in membranes cartridge forms.

Some antiophidic sera suffer unacceptable degradation under heat, and need an alternative method of sterilization for heat-labile pharmaceutical products. Therefore, a strictly control of the sterilization process must be employed including: a) filtering elements integrity test, b) rigorous control of cleaning and manufacturing environment air quality, and c) monitoring of air-suspended particle concentration (Brazilian Pharmacopeia, 1988; European Pharmacopoeia, 2007; British Pharmacopoeia, 2008; United States Pharmacopoeia, 2008).

\section{Microbial resistance to inactivation}

A sterilization process model must be related to the bioburden and to the microorganism inactivation kinetics when exposed to a lethal agent (Luqueta, 2003). Several mathematical models have been developed to help on the Sterility Assurance Level (ASL) calculation, quantifying the bacterial inactivation. Among the most used methods is the microbial inactivation rate constant $(\mathrm{k})$, which determines the inactivation rate as direct related to the number of organisms during a period of time. Thus, each exposure to the lethal agent leads to the inactivation of part of the surviving population. Another important value is the decimal reduction (D) value that is the exposure time required to alter a surviving population by 10 , or the required time for observing one log reduction on the survival rate.

As $\mathrm{D}$ and $\mathrm{k}$ values measure the resistance of a microorganism to a specific inactivation process, both are used in pharmaceutical industry as comparative parameters for validation of sterilization processes and selection for using in parametric release form of the sterile final product (Vessoni Penna, 1994; Vessoni Penna, Machoshvili, 1997).

Resistance to physical or chemical agents used in the sterilization processes are due to many factors including: (i) some genetic-determined microorganism characteristics (i.e. sporulated or unsporulated bacteria); (ii) environmental parameters; (iii) temperature; (iv) nutrient $\mathrm{pH}$; and (v) microorganism growth time or phase (generally more susceptible to inactivation at log phase); ( $v i$ ) the presence of components such as carbohydrates, lipids, proteins, and (vii) the pharmaceutical formulation. In fact, each sterilization process requires optimization to ensure ASL (Vessoni Penna, 1994; Ishisaki, 1998).

Bacteria spores are generally considered as the most resistant form to sterilization processes, despite of their differences. Most viruses have resistance similar to the vegetative form of bacteria and yeasts. Literature shows that some viruses such as the poliovirus and hepatitis B virus present major resistance to inactivation, similar to prions (proteinic aggregates involved in infectious diseases). However, prions are an exception and therefore are not used as reference for sterilizing processes. Fungi spores are generally more sensitive to inactivation if compared to bacterial spores (Luqueta, 2003; Denyer, Baird, 2006). This consideration is more relevant for products of biological origin, such as sera or vaccines, than to traditional pharmaceutical preparations. The determination of the contaminating flora in the local of the manufacturing is of great importance for preventing severe contamination problems of the biological products, including antiophidic sera.

Sterilizing process-resistant microorganisms require the qualification of the selected sterilizing cycles. The use of reference-strain (bioindicators) protocols are commonly developed using preferentially sporulated forms. Formulations containing synthetic drugs use the Bacillus stearothermophilus ATCC 7953 as reference bioindicators in final wet heat sterilization, as well as $B$. subtillis ATCC 9372 in dry heat and ethylene oxide sterilizations, and $B$. pumillus ATCC 27142 spores in irradiation sterilization. Pseudomonas diminuta ATCC 19146 (or Serratia marcescens and Chromobacterium prodigiosum according to Brazilian Pharmacopeia) is the reference bioindicator for the validation of filtering sterilization. $P$. diminuta also serve as a parameter to evaluate the effective retention of the microorganism cells with size compatible to the filtering element nominal pore size, especially the microorganisms that suffer no size reduction when in contact to pharmaceutical preparations (Madsen, Akers, Jornitz, 2006; Brazilian Pharmacopeia, 1988; European Pharmacopoeia, 2007; British Pharmacopoeia, 2008; United States Pharmacopeia, 2008).

However, sometimes based on medicine producers' initiative, no bioindicators are used in thermal or chemical sterilization processes due to the insertion of a contamination source inside a rigorous quality control factory environment. The situation is more severe in the production of an antiserum or other immunobiological products, where 
the insertion of bioindicators in the process is unaccepted. It is important to notice that bioindicators are used in the industry pharmaceutical routine only for thermal-sterilization process. Meanwhile, the filtering element integrity evaluation assay (i.e.; diffusive pressure or bubble point tests) remains for the sterilizing filtering process as a microbiological challenge for the filtering element producer.

The production of a pyrogen-free formulation is also another issue for those of parenteral use. The gram-negative bacteria lipopolysaccharides are the main pyrogens evaluated in the quality control of the injectable producing industry, as they are not inactivated by wet heat sterilizing methods (Pinto, Kanako, Ohara, 2003). Besides, the methods using heat (dry or wet) are not considered for sterilizing antiophidic sera as they cause their inactivation. Therefore, the use of porosity filtering, absorption and sterile manipulation demand strict control in terms of sterility and pyrogenicity assessment.

\section{Antiophidic sera obtaining processes and microbiological control}

Antiophidic sera are sterile immunobiological products used in therapy against snake envenomation. They are produced by using health horses immunized with a mixture of representative snake venoms of each region. Antiophidic sera specifically neutralize the toxic venom compounds of one or more snake species (Vital Brasil Institute, 2006b).

For antisera production, six liters of blood from hyperimmunized horses are conditioned in sterile bags with anticoagulant, at 2 to $8{ }^{\circ} \mathrm{C}$, for sedimentation of the red blood cells. After plasma obtaining, the red blood cells are reinserted into the animals. Then the plasma is submitted to enzymatic treatment, fractionated precipitation and molecular cutoff ultrafiltration to purify a high level of specific immunoglobulins (Brazilian Pharmacopeia, 1988; British Pharmacopoeia, 2008).

Among the main purposes of a filtering process are the solution clarification and sterilization. Both are necessary during antiophidic sera production to guarantee the product quality. The clarification filtering to remove particles as small as $3.0 \mu \mathrm{m}$ is used in the concentrated antisera step. After final dilution and phenol addition, the antisera are submitted to pre-filtering and sterilizing filtering, using 2.0 and $0.22 \mu \mathrm{m}$ cartridges, to obtain the final product, the sterile antisera. After filling the flasks, the final product must be clear, colorless or slightly yellow, free of microbial contaminants and particles or aggregates (United States Pharmacopeia, 2008).

To ensure the quality of sterile products such as the national laboratory produced antiophidic sera, the resolution number 176 of 1996 from ANVISA/MS and Brazilian Pharmacopeia from 1988 (part 1, V.5) determine the performance of physical-chemical, biological (potency, unspecific toxicity and "in vivo" pyrogen) and microbiological tests of many steps products such as plasma, concentrated antisera and final antisera. In fact, regarding pyrogenicity, RDC 249 determines the specific endotoxins detection, indicating the importance of in vitro pyrogen tests to assure a pyrogen-free product (Brasil, 2005). If the specifications are attended, the preparation is packed and tested once more by using a sample and the same parameters, including average volume. The control of the production conditions is fundamental to ensure final product quality since the characteristics of this product do not allow any other sterilization technique but filtering sterilization.

All production system should guarantee the suitability of all installations, methods, processes, protocols and controls used in the fabrication steps of the active pharmaceutical material to ensure the final product quality. These control processes must follow the current legislation recommendations as well as to adapt to diverse fabrication processes (chemical, physical and/or biological). In fact these procedures may be updated to include the latest technological advances.

The Good Manufacturing Practices (GMP) allied to Quality Insurance and Quality Control are important for the whole manufacturing process as they assure the final product identification, purity and safety requirements, based in the pre-set quality policies. Each step has to follow GMP as well as guarantees all specific controls (Brasil, 2003b; 2005).

The control quality tests performed in the final product aim to certify the quality of each product lot concerning to the physicochemical, biological and microbiological patterns. In case of Vital Brazil Institute (VBI), if the product lot is approved, a sample is sent for re-testing and releasing for human use to the National Institute of Health Quality Control (INCQS) from Oswaldo Cruz Foundation (FIOCruz), a national reference lab specialized in immunobiologic analysis (United States Pharmacopeia, 2008).

\section{Importance of manufacturing control}

Sterilization control and other process conditions are effective tools to ensure final product sterility. These tools are base of the parametric release with the main purpose of reducing the number of analysis performed, especially of the sterility test, to confirm the quality of the final pharmaceutical product. According to European Agency 
for the Evaluation of Medicinal Products, the parametric release is the feasibility of ensuring the product quality, through the analysis of the information obtained during manufacture process under Good Manufacture Practices (Wilson, 1998).

Parametric release is not officially accepted by Brazilian legislation, in contrast to United States, where FDA already supports it. Every product that should be sterilized by steam, dry heat or ionizing radiation in its final packing may be released based on the processes data instead of exclusively through sterility tests data, as long as these are validated processes.Parametric release is not an alternative to liberate the commercialization of products sterilized by filtration or aseptic packing, despite there is no restriction for using parametric release in technical point of view. In Brazilian legal terms it will be used only for increasing the guarantee of sterility and quality of a manufactured product lot, even under requirement for a final sterility assay. Compared to the process results, all physicochemical and biological data (preferentially obtained in real time) assure more safety than only the sterility test for both, final packing sterilized products or those differently sterilized (Wilson, 1998). Several requirements should be fulfilled to obtain FDA approval for using parametric release on parenteral products manufacturing including:

$\checkmark \quad$ Products submitted to final sterilization;

$\checkmark \quad 10^{-6}$ sterility assurance level (SAL);

$\checkmark \quad$ Full sterilization cycle description;

$\checkmark \quad$ Cycle qualification: heat distribution and penetration;

$\checkmark \quad$ Minimal process parameters definition;

$\checkmark \quad$ Determination of bioindicators thermal resistance;

$\checkmark$ Comparison of Bioindicators with bioburden;

$\checkmark \quad$ Targeting packing and closing systems;

$\checkmark \quad$ Full written protocol for the entire process;

$\checkmark \quad$ Environmental monitoring program description;

$\checkmark$ Quantitative sterilization cycle monitoring;

$\checkmark \quad$ No permission for administrative revisions such as authorizing product release that do not follow the parametric release specifications.

However, several evaluated aspects of the parametric release are not applicable in filtering sterilizing processes. As an alternative, basic points approached in the sterility warranty system may be used as support to confirm the sterility of a final product (Pharmaceutical Inspection Convention, 2004). They include:

Control of the microbiological contamination burden in the materials used in the process;

Control of the contamination of the manufacturing process, through cleaning and sanitization of the manufacturing area, to avoid microorganisms in product;
Control of the process during different process filtering stages (bubble point and diffusive pressure tests);

$\checkmark \quad$ Prevention of cross-contamination between sterile and non-sterile products;

Maintenance of product integrity (packing);

Test of the aseptic packaging;

Equipment qualification, calibration and maintenance.

In addition to that, the insertion of real time control on the manufacturing process based on Process Technology Analysis (PTA) of critical parameters reinforces the final product sterility assurance (FDA site guidance for industry). Each step of production should follow well established procedures with verification and registering of equipments, working area, documents, materials, documents and available materials (Brasil, 2005).

\section{Controlled environments - clean rooms}

The air is one of the most common causes of microbial contamination, due to particles such as dust and skin cells that carry microorganisms and protect them from oxidation or desiccation (Halls, 2004). As low bioburden level is required prior to the autoclavation of final sterilized products, this is only feasible in an environment controlled in terms of: a) air, b) number of suspended particles, c) cleaning of the area, d) equipments and utensils, and e) workers performance. If a product is not compatible to autoclave sterilization and undergoes through sterilizing filtration or aseptic packaging, the rigorousness of control is even greater, and manufacture area is named clean room or area (Halls, 2004; Denyer, Baird, 2006).

In a non-controlled environment, it is common the formation of different particulate aerosols associated with microbial agents, which represents a significant level of contamination to the pharmaceutical processes (Halls, 2004; Moorfield, 2006). Current filtering and air renewal methods allow reaching the quality for a suitable environment, also considering the demands of the manufacturing critical steps and drug sterility test. RDC 210 of 2003 defines clean room as "an area with the environment control defined in terms of viable and non viable particles contamination, designed, built and used to reduce the introduction, generation and retention of inner contaminants" (Brasil, 2003b).

According to international standards, the quality of the air present in the processing of sterile products in the pharmaceutical industries needs to fulfill strict requirements including: a) limited number of particles of 0.5 to $5 \mu \mathrm{m}, \mathrm{b})$ absence of particles higher than $5 \mu \mathrm{m}$, and c) air filtration (Moorfield, 2006). 
The current technology allows the commercial production of ultra-low particle arrestors (ULPA) air filters with $99.99996 \%$ efficiency for $0.12 \mu \mathrm{m}$ particles. Filters presenting efficiency of $99.9997 \%$ for $0.3 \mu \mathrm{m}$ particles (High Efficiency Particulate Air Filtration - HEPA) are appropriated even for pharmaceutical area restricted purposes (Millipore, 2006).

The most important structural characteristics of clean rooms include presence of horizontal or vertical laminar flow cabinets; directed air flow to avoid room turbulence; positive pressure compared to neighboring uncontrolled areas to avoid contamination; absence of irregularities in the surfaces to avoid particle depositing; and finally an filtrated air system with supply through the ceiling opposed to the exhaustion on the bottom of the room, possibly with a germicide lamp (Bugno, 2001; Denyer, Baird, 2006). Currently the pharmaceutical industries use isolators, which are sterilizable air-sealed chambers, which present HEPA filters. Thus the filtering process of all sterile products may be performed with an easier contamination control, with an expectation of total absence of microorganisms (Pedroso, Allil, 1998).

The present legislation is limited when reporting about the standards parameters for clean rooms. Therefore, most of the sterile product producing and controlling organizations adopt US Federal Standard 209 (A and E), which establish the maximum particles amount (viable or nonviable) per cubic feet, or in the most recent version (E), per cubic meter. In 1997, the ISO also created the standards for the areas classification of the clean room. The areas classified as ISO 3 to 8 are equivalent to 1 to 100,000 classes of US Federal Standard (USFS), respectively (Moorfield, 2006). Table I shows the classification according to ISO and US Federal Standard 209 D and E revisions.

Finally, a new standard for GMP of sterile products

TABLE I - Classification based on number of particles allowed per cubic meter, according to three different systems (United States Federal Standard - USFS)

\begin{tabular}{lcccc}
\hline $\begin{array}{l}\text { USFS - 209D } \\
(1988) \text { Class }\end{array}$ & $\begin{array}{c}\text { USFS } \\
\text { (1992) }\end{array}$ & $\begin{array}{c}\text { ISO 209 } \\
(1997)\end{array}$ & \multicolumn{2}{c}{ Maximum number of } \\
particles $/ \mathrm{m}^{3}$ \\
1 & M1.5 & 3 & 35.3 & $\mathrm{ND}^{\mathrm{b}}$ \\
10 & $\mathrm{M} 2.5$ & 4 & 353 & $\mathrm{ND}$ \\
100 & $\mathrm{M} 3.5$ & 5 & 3,530 & $\mathrm{ND}$ \\
1,000 & $\mathrm{M} 4.5$ & 6 & 35,300 & 247 \\
10,000 & $\mathrm{M} 5.5$ & 7 & 353,000 & 2,470 \\
100,000 & M6.5 & 8 & $3,350,000$ & 24,700 \\
\hline
\end{tabular}

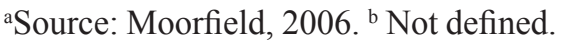

established four classes, considering the particles amount of a resting or working room (Table II). The "resting" condition involves the complete installation with full equipments, but without the workers. The "working" situation indicates the room in the operational mode, with a number of workers.

The first class (A) corresponds to critical operation locations (i.e. packaging and aseptic connection manipulation). The second class (B) is proper for environments close to those where the product is prepared and packaged. The values are close to those established by the ISO and US Federal Standard systems. Thus A and B are equivalent to classes 100, M 3.5 and ISO 5, and represent required areas for producing and controlling sterile products according to RDC 210 (Brasil, 2003b).

TABLE II - Classification for sterile products manufacturing in accord to GMPa

\begin{tabular}{|c|c|c|c|c|}
\hline \multirow{3}{*}{ Degree } & \multicolumn{4}{|c|}{ Maximum numberof particles / $\mathbf{m}^{3}$} \\
\hline & \multicolumn{2}{|c|}{ Resting } & \multicolumn{2}{|c|}{ Working } \\
\hline & $\begin{array}{c}0.5 \text { to } \\
5.0 \mu \mathrm{m}\end{array}$ & $>5.0 \mu \mathrm{m}$ & $\begin{array}{c}0.5 \text { to } \\
5.0 \mu \mathrm{m}\end{array}$ & $>5.0 \mu \mathrm{m}$ \\
\hline A & 3,500 & 0 & 3,500 & 0 \\
\hline B & 3,500 & 0 & 350,000 & 2,000 \\
\hline $\mathrm{C}$ & 350,000 & 2,000 & $3,500,000$ & 20,000 \\
\hline $\mathrm{D}$ & $3,500,000$ & 20,000 & ND & $\mathrm{ND}^{\mathrm{b}}$ \\
\hline
\end{tabular}

a Source: WHO Technical report Series number 902, 2002. In: Brasil, 2003.

${ }^{\mathrm{b}}$ Not defined.

The parameter involving the quality of the air present in the clean area is added to others, when using the parametric release to enable the commercialization of a safer parenteral product of any volume.

\section{Antiophidic sera sterility test}

Antiophidic sera sterility test aims to detect viable microorganisms on the evaluated product (Brazilian Pharmacopeia, 1988). Over the years, this test is continually improved to increase microbiological quality and safety of sterile products.

Despite the parenteral therapy was created in the last century, the first official method for the sterility test was reported in British Pharmacopoeia, in 1932. The regulation established the test for liquid form products and the use of peptone broth and $37^{\circ} \mathrm{C}$ incubation for 5 days, for detecting aerobic bacteria. In 1936, the eleventh edition of United States Pharmacopoeia (USP) adopted 
the same methodology. The analytical resource has been continually improved to allow detection of anaerobic and microaerophile microorganisms.

In the thirteenth edition of USP, the test was extended to fungi detection, using honey containing culture medium and incubation at 22 to $25^{\circ} \mathrm{C}$ for 15 days. The innovation occurred in 1964, by officialization of the indirect sample inoculation (membrane filtration) method by the FDA, as an alternative to the direct inoculation method. In 1970, USP introduced the membrane filtration technique, which was followed by the Brazilian Pharmacopeia in 1976. After 1988, a longer incubation period of 14 days was established for direct and indirect methods (Pedroso, Allil, 1998; Bugno, 2001; Pinto, Kaneko, Ohara, 2003).

The improvement of the sterility test aims to assure the quality of the sterilizing process and of the sterile products considering the probabilistic and contamination risks. However this assay becomes extremely timeconsuming also increasing the production time, which is target of criticism. Thus it is necessary to evaluate when this procedure is essential or if it may be replaced by alternative approaches, such as the parametric release.

\section{Sampling}

The sterility test is a destructive assay that cannot be applied to the whole lot. Therefore, this test should be based on an essentially statistic sampling method where the number of samples to be tested should be representative of the whole lot. The results are determined based on the number of the selected samples and of the contamination level, aiming to safely extend these data to the entire lot (Peixoto, Oda, 1984a, b).

The sampling of the packaged products generally follows a proportionality within the lot. By the rule, 10-20 unities of each parenteral product lot are selected, depending on the total volume of each pack or flask. In fact, the approval probability of a contaminated lot is reduced when the size of sample is increased (Pinto, Kanako, Ohara, 2003).
According to Peixoto and Oda (1984b), the data obtained from a sterility test performed with non-representative statistically samples may not be safely extended to the entire lot. This means that a significant small number only serves to detect a high level of contaminated unities. Therefore, the British, American and European Pharmacopeias established a minimum number of unities to be selected and tested based on the lot size. For lots smaller than 100 unities, $10 \%$ or 4 unities (the higher value) should be tested whereas for lots between 100 and 500 unities, or higher than 500 unities, the selections are 10 unities, and $2 \%$ or 20 unities (30 unities according to British Pharmacopoeia) - the lowest value - respectively. The Brazilian Pharmacopeia establishes the test of at least 20 unities or $10 \%$ of lots smaller than 199 unities. According to the Brazilian Pharmacopeia, the proper sampling for raw material is based on the root square of the total number of recipients of the lot.

The filling volume of antiophidian sera $(10 \mathrm{~mL})$ is bigger than those of some vaccines. According to the British and American Pharmacopeias the minimal amount of sampling of each antiophidian sera recipient is of $5 \mathrm{~mL}$ in contrast to European Pharmacopeias $(2 \mathrm{~mL})$. The Brazilian Pharmacopeia rules for injectable medication are shown in the Table III.

Source: Adapted from Brazilian Pharmacopeia, 1988. ${ }^{\text {a }}$ For volumes higher than $100 \mathrm{~mL}$, it is recommended the membrane filtering method using the whole recipient volume.

\section{Inoculation methods}

Currently, the Brazilian, American, British and European Pharmacopeias indicate two culture medium inoculation forms mainly due to availability, feasibility, efficiency or economical limitations.

\section{Direct inoculation}

In this method, samples products are inoculated in broth or solid culture medium, using pipette, syringe

TABLE III - Correlation between the sample volumes and culture media in the direct and indirect (membrane filtering) methods

\begin{tabular}{lccc}
\hline $\begin{array}{l}\text { Total Volume of full } \\
\text { recipient }(\mathrm{mL})\end{array}$ & $\begin{array}{c}\text { Mínimal Volume of the } \\
\text { product to be tested }(\mathrm{mL})\end{array}$ & $\begin{array}{c}\text { Minimal Volume of the culture } \\
\text { media }(\mathrm{mL}) \text { Direct Method }\end{array}$ & $\begin{array}{c}\text { Minimal Volume of the culture } \\
\text { media }(\mathrm{mL}) \text { Filtering Method }\end{array}$ \\
\hline$<10$ & $1 \mathrm{~mL}$, or full amount $<1 \mathrm{~mL}$ & 15 & $100^{\mathrm{a}}$ \\
$11-50$ & 5 & 40 & 100 \\
$51-100$ & 10 & 80 & 100 \\
\hline
\end{tabular}

Source: Adapted from Brazilian Pharmacopeia, 1988. ${ }^{\mathrm{a}}$ For volumes higher than $100 \mathrm{~mL}$, it is recommended the membrane filtering method using the whole recipient volume. 
or direct spill, and are incubated for 14 days at proper temperature. Due to difficulties on performing filtering processes, this method is commonly used for suspended particles products or those with high density.

The advantages of direct inoculation method include feasible and easy process that requires brief manipulation and training, with low accidental contamination risks. In contrast, disadvantages are low representativeness of the sample volume, inhibitory agent residues (preservatives), restriction to large volumes, and risks of approving a contaminated lot (Fracalanzza, 2005; Vital Brasil Institute, 2006c).

\section{Indirect inoculation (Filtering}

It was developed in 1957 by Holdowsky and documented by FDA and United States Pharmacopoeia in 1964 and 1970 respectively (Pedroso, Allil, 1998). The membrane filtration method is widely used in sterile products manufacturing industries. The Vital Brazil Institute uses this methodology for testing antiophidic sera during fabrication of bulk and packaged products.

The method consists of filtering a specific volume using a nitrocellulose membrane with hydrophobic border, $47 \mathrm{~mm}$ diameter and maximum nominal porosity of $0.45 \mu \mathrm{m}$ (or $0.22 \mu \mathrm{m}$ ) (Millipore, 2006). The $0.45 \mu \mathrm{m}$ membrane allows the detection of microorganism in samples submitted to the sterility tests whereas the $0.22 \mu \mathrm{m}$-membrane completely retains viable and nonviable particles in both sterilizing filtering processes and sterility tests. The Vital Brazil Institute uses $0.22 \mu \mathrm{m}$ membrane for sterility tests and sterilizing filtering processes (Vital Brazil Institute, 2005).

The filtering system used in the indirect sterility test consists of a base supported receptacle, under a kitasato attached filtering membrane. The filtering process is performed under negative pressure using an oil free vacuum pump, and flow of 55 to $75 \mathrm{~mL} / \mathrm{min}$ (Brazilian Pharmacopeia, 1988; Koga, 1997). After sample filtration, the membrane needs to be washed with a sterile $1 \%$ peptonated solution to avoid phenol residues into the culture medium, which might cause a false negative result. The transference of the membrane into the culture medium may be performed using a sterile clamp. The division of the membrane in two pieces for using with different culture mediums decreases the costs of the test and is optional. In case of the presence of microorganisms in the sample, they will be retained in the membrane and back to grow after incubation in enriched mediums and proper temperature and time (Fracalanzza, 2005).

The advantages of this method include: the noncarrying of inactivating agents and/or preservatives to the culture medium, and specially, the possibility of testing injectables with large volume content $(\leq 5$ liters), leading to a higher statistical representativeness compared to the direct method. Disadvantages include: high cost process and product manipulation, training requirement and sample limitation, restriction to products that are solubilized or in suspension. Table IV compares the advantages and disadvantages of the direct and indirect inoculation methods based on different factors.

In VBI, all sterility tests are performed using the membrane filtration (indirect) method. The only exception is in microbiological trial of equine plasmas, when direct method is used, due to the high fibrin level that rapidly saturate the filtering member and the absence of preservatives.

\section{Culture conditions}

Before performing the test, the viable residual contaminant or the product recontamination agents are unknown for the technician/analyst. Therefore, the selection of the culture medium is important, as it should offer ideal conditions for different microorganisms growth, fulfilling also their nutritional demanding (Bugno, 2001).

The current pharmaceutical regulations determine the liquid culture medium use for promoting bacteria,

TABLE IV - Comparison of direct inoculation and indirect (membrane filtering) methods

\begin{tabular}{lcc}
\hline Factor & Direct Inoculation & Indirect - Membrane Filtering \\
\hline Sensitivity & Low & High \\
Precision & Low & High \\
Indication (Volume) & Suitable for small volumes $(<100 \mathrm{~mL})$ & Suitable for bigger volumes $(>100 \mathrm{~mL})$ \\
Use in products with growth inhibitors & Not suitable & Suitable if inhibitors eliminated in rinsing step \\
Performance & Fast and easy & Slow and special equipment demands \\
Manipulation & Low & High (more training) \\
Cost & Low & High \\
\hline
\end{tabular}

Source: Fracalanzza, 2005. 
fungi and yeast growth. Thus, the minimum required is the use of two types of enriched culture medium that allow growth of the highest number of contaminants, as many as possible.

The international and national pharmacopeias indicate the use of thioglycolate broth containing resarzurine, which promotes growth of anaerobic, mesophilic aerobic and microaerophile bacteria when incubated at $30-35^{\circ} \mathrm{C}$; and casein-soy broth for detection of yeasts and psychrophile aerobic microorganisms after incubation in $20-25^{\circ} \mathrm{C}$. The minimum volume necessary is $100 \mathrm{~mL}$ for both medium culture and this protocol is adopted by VBI (Vital Brasil Institute, 2005 2006c).

The professed time for culture medium incubation is of 14 days (Brazilian Pharmacopeia, 1988; European Pharmacopeia, 2007; British Pharmacopoeia, 2008; United States Pharmacopeia, 2008). This increase of time is an improvement of the method as it allows the detection of slow growth microorganisms and those "stressed" by sterilizing process exposition or antimicrobials present in the product (Pedroso, Allil, 1998).

\section{Data Analysis}

A representative sample of a lot only fulfill the requirements of the sterility test when no microorganism growth is detected macroscopically in liquid (turbidity) or solid (colonies) medium after culture during 14 days (Fracalanzza, 2005; Vital Brazil Institute, 2005 and 2006c).

Overall the acceptance criteria of different regulations are similar. According to rule $\mathrm{n}^{\circ} 176$, adopted by VBI, if there is no detection of microorganisms in the medium on the original test, the lot is considered as sterile and approved (Brasil, 1996). In contrast, if any microorganism is detected in the medium, a re-test is performed to assure that the contamination is from the product and not from the test manipulation. If the first re-test is positive, the antisera lot is disapproved whereas if it is negative, a second test is performed with double of samples. If the result is negative once more, the lot is approved whereas if a microorganism growth is detected, the lot is disapproved (Table V).

The Brazilian Pharmacopeia still allows another possibility if the contamination persists in the first retest. On that case, the microorganisms isolated in the two occasions (initial test and first re-test) should be compared. If they are the same contaminant, the lot is direct disapproved but if they are different, a second re-test may be performed using the double number of samples. If the contamination is not detected the lot should be approved (Table VI).

TABLE V - Interpretation of sterility test data according to rule $n^{\circ} 176$

\begin{tabular}{lllll}
\hline $\begin{array}{l}\text { Class } \\
\text { evaluation }\end{array}$ & Test $(0,4 \sqrt{ } \mathrm{N})$ & $1^{\circ}$ Re-test $(0,4 \sqrt{ } \mathrm{N})$ & $2^{\circ}$ Re-test $(0,8 \sqrt{ } \mathrm{N})$ & Final \\
\hline A & negative growth & - & - & Satisfactory \\
B & positive growth & negative growth & negative growth & Satisfactory * \\
C & positive growth & negative growth & positive growth & Unsatisfactory ** \\
D & positive growth & positive growth & - & Unsatisfactory*** \\
\hline
\end{tabular}

$\mathrm{N}=$ total number of vials from the lot. Source: Brazil, 1996.

TABLE VI - Interpretation of the sterility test data

\begin{tabular}{lcccc}
\hline Class & $\begin{array}{c}\text { Original Test } \\
\text { Sampling }=(0.4 \sqrt{ } \mathrm{N})\end{array}$ & $\begin{array}{c}1^{\circ} \text { Re-test } \\
\text { Sampling }=(0.4 \sqrt{ } \mathrm{N})\end{array}$ & $\begin{array}{c}2^{\circ} \text { Re-test } \\
\text { Sampling }=(0.8 \sqrt{ } \mathrm{N})\end{array}$ & Final Evaluation \\
\hline A & negative growth & - & - & Satisfactory \\
B & positive growth & negative growth & - & Satisfactory \\
C & positive growth & positive growth & - & Unsatisfactory* \\
D & positive growth & positive growth & negative growth & Satisfactory ** \\
E & positive growth & positive growth & positive growth & Unsatisfactory*** \\
\hline
\end{tabular}

$\mathrm{N}=$ total number of vials from the lot; * Same microorganism detected in the original test and first re-test; ** Different microorganisms isolated in the original test, first re-test and negative second re-test; ${ }^{* * *}$ Contamination in the three tests, even by different microorganisms. Source: Brazil, 1996 


\section{The validation and its applicability in antiophidian sera manufacturing process}

Incidents reported in the 70's decade about septicemia and deaths due to the parenteral use of contaminated material revealed the necessity of improvement of the current sterility tests, to assure the quality, safety, and efficiency of the product. On that purpose the monitoring of the whole manufacturing process and the validation of all steps including the sterility test became mandatory for sterile product manufacturing (Bugno, 2001).

According to the RDC $n^{\circ} 210$ and RDC $n^{\circ} 899$ (Brasil, 2003b and c), the validation may be defined as a documented act, which assures that any procedure, process, equipment, material, operation or system, really leads to the expected results. Due to the statistical limitations of the sterility test, it is necessary to use validated assays that present sensibility, accuracy, reproducibility and no false results caused by external factors. Besides, all installations and parameters such as the bacteriostatic and fungistatic effects of the preservative system should be previously qualified (Denyer, Baird, 2006). Simultaneously the determination of the contamination and of the operational conditions of the clean room where the assay is performed also contributes to assure the validity of the assay. The chapter 1208 of the American Pharmacopeia Sterility testing - Validation of isolator systems is a guideline for validation of the isolation system used in the sterility test. This system allows to eliminate the bioburden in the controlled environment where is performed the analysis. The validation of the sterility test per se is presented in chapter 71 Sterility tests.

\section{Environment qualification}

It certifies and monitors the assay performance physical area including regarding the microorganisms presence (Pinto, Kanako, Ohara, 2003). The air sampling should be performed in specific points during the area normal activity through static sampling or air collectors. The same parameters should be evaluated in the test area. The air microbiological quality and the amount of suspended particles should be monitored by both plating and air centrifuge samplers and compared to US Federal Standard recommended limits (Table VII) (INCQS/Fiocruz, 2005a e 2006b).

Air collecting sampling is performed by using equipments with air suctioning filters for retain eventual particles. The filters are placed in the culture medium for monitoring the microbial growth and quantifying the amount of particle per volume of filtered air. On that purpose the Colonies Forming Units (CFU) amount are
TABLE VII - Microbial contamination limits recomended by US Federal Standard

\begin{tabular}{lccc}
\hline $\begin{array}{l}\text { Class } \\
\text { (Level) }\end{array}$ & $\begin{array}{c}\text { Particles } \\
\text { Sampled by } \\
\text { Air Colectors } \\
\text { (UFC/ } \text { m }^{3} \text { of air) }\end{array}$ & $\begin{array}{c}\text { Sedimentation } \\
\text { by Static } \\
\text { Sampling } \\
\text { (UFC/4 h) }\end{array}$ & $\begin{array}{c}\text { Rodak Contact } \\
\text { Plate }\end{array}$ \\
(UFC/placa) $^{\circledR}$
\end{tabular}

Available in: http:// www.morfield.co.uk.

determined after plate incubation for 5 days. The surface microbial control may be performed by using Rodac ${ }^{\circledR}$ plates (Peixoto, Oda, 1984b; Halls, 2004).

\section{Workers qualification}

The operators are potential causes of contamination during assay. Since the microorganisms are always associated to skin, hair and nails, among others, the operator should receive specific training to guarantee the assay success (Halls, 2004). The operators should be aware of the importance of the assay and of their own role in immunobiological quality control. An intensive training program with the inclusion of asepsis and biosafety concepts is a fundamental resource for reducing false-positive results (from operation contamination) that should not exceed $2 \%$. Operators with infectious disease may not perform sterility assays. Operational control also involves using proper clothes, equipments and sterile materials (INCQS/ Fiocruz, 2005b).

\section{Validation}

It must include the analysis of sterility, the culture medium growth features, and of the preservative removal efficiency from the product during the washing step using peptone solution. Most of the preservative are from phenolic derivatives class. VBI uses $0.35 \%$ phenol in the antiophidian sera preparation (Brazilian Pharmacopeia, 2003). The preservative are necessary to maintain the pharmacologic integrity and should present specific features such as: a) no interaction with the active drug, b) potent and large spectrum antimicrobial profile that is easily blocked or attenuated when necessary, c) atoxic in the allowed concentration, and d) stable and soluble (Pimenta, 2005).

The evaluation of the preservatives/antimicrobial presence in the product determines the bacteriostatic and antifungal effects. This intends to prevent false-negative results and establish the best membrane rinsing system to be used in the end of each filtration. It consists in inocu- 
lating the final rinsing into proper culture medium with proper microorganisms. After adequate period of time and temperature, the microbial growth observed should reveal the complete removal of residual inactivators as well as of preservatives and antimicrobials (Pedroso, Allil, 1998).

Due to the specific features of the sterility test and the rigid criteria used for the interpretation of the results, it is necessary to confirm the capacity of the culture medium of allowing recovery and growth of even a reduced number of viable microorganisms. Therefore, the sterility test must be performed for each lot of prepared medium. It consists of inoculation of 10 to 100 UFC of referencestrains at proper temperature for at least 7 days to detect the microbial growth (positive control) (Table VIII). In addition the sterility of the medium should be confirmed by performing the negative control (medium not inoculated) of the sterility test (Brazilian Pharmacopeia, 1988; Fracalanzza, 2005; United States Pharmacopeia, 2008).

\section{Assay invalidation}

The sterility assay is invalidated due to: a) unsatisfactory microbiological environment monitoring, $b$ ) human flaw on analysis procedure, c) microbial growth in negative control and/or absence of growth in the positive control, and d) preservative interference in the test result. In case of invalidation, the test must be performed once more using the same number of sample of the original test, besides preventive actions for controlling it (United States Pharmacopeia, 2008).

\section{Pyrogen Control}

A particular attention to pyrogen presence should be taken for producing injectables. The detection of pyrogen agents may be difficult in in vivo assays in case of immunobiologics and antisera that may generate a fever reaction when administered, due to the iatrogenic feature. On that case, the alternative suggested by RDC 249 (Brasil,
$2005)$ is the in vitro test. The detection is based on the coagulation of a proteinic homogenate from horseshoe crab hemolymph (Limulus polyphemus) in presence of gramnegative bacteria LPS (Pinto, Kanako, Ohara, 2003). It is interesting to notice that this sensible assay must fulfill extremely restricted validation criteria, which reduces the high incidence of false-positive or negative results. The test was accepted by FDA in 1982 and predicts the use of a pre-validate kit that include lyophilized pyrogen reagent (proteinic homogenate from hemolymph), lyophilized reference Escherichia coli endotoxin (in international unities) and pyrogen-free water (BET-bacterial endotoxin free-water). Once properly reconstituted with BET water, the initial and essential procedure for the execution of the test with several samples involves negative and positive controls.

\section{Positive control}

It is performed by incubating $0.1 \mathrm{~mL}$ of pyrogen reagent plus $0.1 \mathrm{~mL}$ of diluted endotoxin (as described by the kit) in a pyrogen-free test tube for $30 \mathrm{~min}$ at $37^{\circ} \mathrm{C}$. Expected result: jellification.

\section{Sample positive control}

It is performed by incubating $0.1 \mathrm{~mL}$ of pyrogen reagent plus $0.1 \mathrm{~mL}$ of diluted endotoxin (as described by the kit) and $0.1 \mathrm{~mL}$ of sample in a pyrogen-free test tube for $30 \mathrm{~min}$ at $37^{\circ} \mathrm{C}$. Expected result: jellification.

\section{Negative control}

It is performed by incubating $0.1 \mathrm{~mL}$ of pyrogen reagent and $0.1 \mathrm{~mL}$ of $B E T$ water in a pyrogen-free test tube for $30 \mathrm{~min}$ at $37^{\circ} \mathrm{C}$. Expected result: absence of jellification.

It is interesting to observe the sample positive control. If there is no jellification, the interference (inhibitor) presence is implied. Several authors reported the interference of calcium chelators such as EDTA (used as

TABLE VIII - Reference strains used in culture medium validation

\begin{tabular}{lcc}
\hline Microorganism & Respiratory Metabolism & Reference Culture Medium \\
\hline $\begin{array}{l}\text { Bacillus subtilis / Kocuria Rhizophila } \\
\text { ATCC } 6633\end{array}$ & Aerobic & Tioglicolate or Casein-Soy \\
Micrococcus luteus ATCC 9341 & Aerobic & Tioglicolate \\
Bacterioides vulgatus ATCC 8482 & Anaerobic & Tioglicolate \\
Clostridium sporogenes ATCC 11437 & Anaerobic & Tioglicolate \\
Candida albicans ATCC 10231 & Aerobic & Casein-soy
\end{tabular}

Source: Fracalanzza, 2005. 
preservative) that avoid the jellification reaction (Cooper, Weary, Jordan, 1997). If not solved by the interference elimination, the inhibition of the positive reaction by the sample avoids the use of in vitro assays for endotoxin monitoring and detection in injectable preparations. If the sample does not cause iatrogenic fever reaction, in vivo assays may be used as alternative method (Pinto, Kanako, Ohara, 2003).

\section{FINAL CONSIDERATIONS}

Absence of microorganisms and consistent results in the sterility and pyrogenic tests are some of the goals to be reached for antiophidian sera final products. Therefore the control performed during the manufacturing of these products significantly contributes to reach these goals. The insertion of these controls in real time and direct coupled to the manufacturing process reinforced the applicability of the parametric release concept for assuring the sterility of the final product.

In case of detecting microbial contamination during plasma processing and mainly in the sera produced at large scale, the product may be reprocessed and submitted to a new sterilizing filtration process. This following from the raw material acquisition till the filling of the product, allow many corrective actions to assure the quality of antiophidian sera supplied for Brazilian Health Minister.

The sterility test is: a) part of the microbiological control of the antiophidian sera production, b) an important assay for the institutions involved on producing these sera and c) a target for continue studying and improving of its efficacy (Brasil, 1996). In fact, the level of microbiological reliability of sterile products increased due to the several productive advances including the improvement of methodologies for contaminants detection and the application of more restricted validation criteria (Denyer, Baird, 2006).

The severity in the interpretation of the results based on a regulatory literature is also important to avoid falsenegatives (low level of undetected contamination) or falsepositives (rejection of a lot that may be considered sterile but that failed in the sterility test) results. Both cases compromise months of works due to: a) the reprocess of the product, b) lost of a false-positive lot, c) re-test needing, and d) processing for identifying the contamination origin that are always time and workers consuming (Pedroso, Allil, 1998; Fracalanzza, 2005).

All analyzed Pharmacopeias indicated the use of $0.45 \mu \mathrm{m}$-membrane in the sterility test. These monographs involve all sterile parenteral and immunobiologics products that, besides the hyperimmune sera, also include more dense vaccines that contain adjuvants for which 0.22 $\mu \mathrm{m}$-membranes are not appropriate. As antiophidian sera are easily filtrated in $0.22 \mu \mathrm{m}$-membranes, VBI correctly choose these membranes for having a safer profile of preparation (Brazilian Pharmacopeia, 1988; European Pharmacopeia, 2007; British Pharmacopoeia, 2008; United States Pharmacopeia, 2008).

The validation of all processes that guarantee the sterility in all aspects including environmental, operational and methodological are considered important as contributes to obtain satisfactory and safety results. Importantly there are intrinsic limitations of the sterility test despite the methodological advances developed during all these years. Probably the most limiting factor is the statistical parameter of the assay. As this test is destructive, not all flasks or pack are submitted, which generated unsureness about the sterility of the whole lot. Therefore the sample selection criteria are always in debate. Currently the test detects high contamination levels whereas the ability of detecting rare contamination is limited unless the number of samples is high (Peixoto, Oda, 1984; Pinto, Kaneko, Ohara, 2003).

Another limitation of the sterility test is related to not allowing growth of all types of microorganisms. The test provides perfect conditions for bacteria, fungi and yeast development but still not for virus. Even bacteria and fungi, the negative results are extended values (Denyer, Baird, 2006). Besides two culture media may be not sufficient to fulfill the nutritional requirements of some specific microorganisms, and/or the incubation temperature may not allow the development of all psychrophile and thermophile microorganism (Bugno, 2001).

Despite of allowing the recovery of microorganisms for a period of $14 \mathrm{~h}$, the sterility test may also fail due to the absence of a mechanism of recovery of the microbial cells subletally affected by sterilizing processes or by the contact of antimicrobials/preservatives added to the antiophidian sera. Therefore the absence of microorganism growth detected by a sterility test does not mean $100 \%$ assure the complete product sterility (Bugno, 2001; Pedroso, Allil, 1998).

In the manufacturing of sterilizing filtration submitted products, the applicability of the parametric release is controversial. The Brazilian legislation already accepts the data of physic chemistry and potency controls performed with antiophidian sera produced in large scale. The exceptions are the sterility and pyrogen tests as they can be altered during the filling step. As alternative, it may be considered the parameters observed in the sterility ensuring system as base for supporting the final sterility of the product.

In addition, the Process Analytical Technology 
(PAT) that associates control parameters (i.e. conductivity, total organic carbon value in the water production line for injectables products and suspended particles, temperature and humidity of the manufacturing environment) allowed not only the statistical analysis of the results in real time as well as the control system that performs adjustments to get the perfect work condition (Guidance for industry - PAT, 2003). On that way the reliability of the sterility test reaches the requested levels for assuring the safety of antisera and vaccines produced to the final consumer.

Therefore the sterility test is a reference assay that should be considered among several controls measurements to decide if a sterile product fulfills the legislation requirements. Due to the limitations, the Good Manufacture Practices should be used by any institution that produces sterile medicaments and immunobiologicals (i.e. VBI), searching continuously for quality excellence and consequently safety for these products. This review hopes to contribute for the development of new microbial detection methods comparable or even better than the current ones to promote a major efficiency in the microbiological control of these products, with fulfillment of the current legislation and of the consumers expectation.

\section{ACKNOWLEDGEMENTS}

We thank FAPERJ, CNPq and UFF for the financial support and fellowships.

\section{REFERENCES}

BRASIL. Portaria n ${ }^{\circ} 176$, de 11 de novembro de 1996. A Agência Nacional de Vigilância Sanitária aprova as Normas Técnicas de Fabricação e controle de Qualidade da Vacina contra a Raiva Uso Humano (CCL) Fuenzalida - Palácios Modificada, na conformidade do anexo desta Portaria. Diário Oficial da União. Brasília, 12 novembro de 1996. Available at: <http://e-legis.anvisa.gov.br/leisref/public/ showAct.php?id=791\&word=\#>.

BRASIL. RDC n 249 , de 13 de setembro de 2005. Determina a todos os estabelecimentos fabricantes de produtos intermediários e de insumos farmacêuticos ativos, o cumprimento das diretrizes estabelecidas no regulamento técnico das boas práticas de fabricação de produtos intermediários e insumos farmacêuticos ativos. Diário Oficial da União. Brasília, 26 setembro de 2005. Available at: <http://e-legis.anvisa.gov.br/leisref/public/showAct. php?id=18892\&word=>.
BRASIL. RDC n 79, de 11 de abril de 2003. Agência Nacional de Vigilância Sanitária aprova a utilização de compêndios farmacêuticos internacionais como referência no controle de qualidade de insumos e produtos farmacêuticos brasileiros e dá outras providências. Diário Oficial da União. Brasília, 14 de abril de $2003^{\mathrm{a}}$. Available at: $<$ http://e-legis.anvisa.gov. br/leisref/public/showAct.php?id=10936>.

BRASIL. RDC n ${ }^{\circ} 210$, de 04 de agosto de 2003. A Agência Nacional de Vigilância Sanitária aprova o Guia de Boas Práticas para Fabricação de Medicamentos. Diário Oficial da União. Brasília, 14 de agosto de 2003b. Available at: <http://e-legis.anvisa.gov.br/leisref/public/showAct. php?id $=22321 \&$ word $=>$.

BRASIL. RDC n 899, de 29 de maio de 2003. A Agência Nacional de Vigilância Sanitária aprova o Guia para validação de métodos analíticos e bioanalíticos. Diário Oficial da União. Brasília, 02 de junho de 2003c. Available at: <http://e-legis.anvisa.gov.br/leisref/public/showAct. php?id=15132\&word $=>$.

BRAZILIAN PHARMACOPEIA. 4.ed. São Paulo: Ed. Atheneu, 1988. p.1320-1321.

BRITISH PHARMACOPOEIA. London: Her Majesty's Stationary Office, 2008. p.3500-3501.

BUGNO, A. Esterilidade: validação de metodologia e propostas de otimização de resultados. São Paulo, 2001. 188p. [Dissertação de Mestrado. Faculdade de Ciências Farmacêuticas. Universidade de São Paulo].

COOPER, J.F.; WEARY, M.E; JORDAN, F.T. The impact of non-endotoxin LAL-reactive materials on Limulus amebocyte lysate analyses. J. Parenter. Sci. Tecnol., v.51, n.6, p.2-6, 1997.

DENYER, S.P.; BAIRD, R.M. Guide to Microbiological controle in pharmaceuticals and medical devices. 2.ed. New York: Ed. CRC PR I LIC, 2006. 482 p.

EUROPEAN PHARMACOPOEIA. 6.ed. Strasbourg: Council of Europe, 2007. p.4392-4393.

FRACALANZZA, S.E. Controle de qualidade na indústria: por que fazer e como fazer. Rio de Janeiro: Ed. Universidade Federal do Rio de Janeiro, 2005. 38 f. 
FUNASA. Guia Brasileiro de Vigilância Epidemiológica. 5. ed. Brasília: Ed. FUNASA/MS/Centro Nacional de Epidemiologia, 1998. Chap. 5.1, p.1-4.

GUIDANCE FOR INDUSTRY - PAT. A Framework for Innovative Pharmaceutical Manufacturing and Quality Assurance. CDS029|CDERGUID|5815dft.doc 08/25/03.

HALLS, N. Microbiological contamination control in pharmaceutical cleanrooms. New York: Ed. Sue Horwood Publising Limited, 2004. 117 p.

HINRICHSEN, S. L. Biossegurança e Controle de Infecções: Risco Sanitário Hospitalar. Rio de Janeiro: Ed. MEDSI, 2004. $896 \mathrm{p}$.

INCQS/FIOCRUZ. Controle ambiental das áreas controladas do Setor de Esterilidade. In: Manual da qualidade. Rio de Janeiro: INCQS/FIOCRUZ, 2005a. Seção 10. (POP n ${ }^{\circ}$ 65.3220.008)

INCQS/FIOCRUZ. Ministério da Saúde. Ensaio de Esterilidade Bacteriana e Fúngica em Imunobiológicos Realizado em Área Limpa. In: Manual da qualidade. Rio de Janeiro: INCQS/FIOCRUZ, 2005b. Seção 10. (POP n $\left.{ }^{\circ} 65.3220 .005\right)$.

ISHISAKI, E.T. Validação da autoclave na esterilização de solução parenteral. São Paulo, 1998. 129 p.[Dissertação de Mestrado. Departamento de Tecnologia BioquímicoFarmacêutica. Faculdade de Ciências Farmacêuticas da Universidade de São Paulo].

KOGA, O.E. Esterilização por filtração. Rev. Farm. Bioquím. da USP?, v.33, supl.1, p.21-25, 1997.

LUQUETA, G.R. Esterilização por calor e a cinética de morte microbiana. 2003. Available at: http:// www.baumer.com. br/artigos/artigo_esterilizacao_calor.pdf. Accessed on: 23 mar. 2007.

MADSEN, R; AKERS, J.E.; JORNITZ, M.W. The use of model organisms in sterilizing filtration. Pharmaceutical technology aseptic processing supplement: s38-s42.

MILLIPORE. Product catalogue: membrane filters. Available at: $<$ http://www.millipore.com. $>$ Accessed on: $5^{\text {th }}$ sep. 2006 .

MOORFIELD. Classification of cleanrooms/US Federal Standard. Available at: <http://www.moorfield.co.uk $>$. Accessed on: 15 aug. 2006.
PEDROSO, A.L.C.; ALLIL, M.C.A. Controle microbiológico na produção farmacêutica: técnicas atuais e novas tendências. Rio de Janeiro: Seminário Millipore, 1998. 31 p.

PEIXOTO, E.M.A; ODA, L.M. Normas técnicas para controle de esterilidade de produtos imunobiológicos, medicamentos e dispositivos esterilizados. Rio de Janeiro: Ed. FIOCRUZ/ INCQS, 1984a. 16 p.

PEIXOTO, E.M.A; ODA, L.M. Testes de esterilidade de produtos biológicos. In: Controle de qualidade de produtos imunobiológicos. Rio de Janeiro: Ed. FIOCRUZ/INCQS, 1984b. $17 \mathrm{f}$.

PHARMACEUTICAL INSPECTION CONVENTION. Pharmaceutical Inspection Cooperation Scheme. PI $005-$ 2. Recommendation on Guidance on Parametric Release. Geneva: 2004. 21 p.

PIMENTA, C.M.C. Conservantes mais utilizados em farmacotécnica. Niterói, 2005. [Monografia de Farmacotécnica. Departamento de Tecnologia Farmacêutica e de Cosméticos. Faculdade de Farmácia. Universidade Federal Fluminense]. Available at: $<$ http://www. portalfarmacia.com.br/principal/ conteudo.asp?id $=271>$. Accessed on: $5^{\text {th }}$ sep. 2006.

PINTO, T.J.A.; KANEKO, T.; OHARA, M. 2 ed. Controle biológico de qualidade de produtos farmacêuticos, correlatos e cosméticos. São Paulo: Ed. Atheneu, 2003. $325 \mathrm{p}$.

RUNKLE, R.S.; PHILLIPS, G.B. Microbial contamination control facilities. New York: Ed.Van nostrand Reinhold Company, 1969. Chap.1, 2, p.8-19.

TRABULSI, L.R.; ALTERTHUM, F. Microbiologia. 4.ed. São Paulo: Ed. Atheneu, 2005. Cap.7, p.57-65.

UNITED STATES PHARMACOPEIA. Rockville: Ed. The United States Pharmacopeal Convertion, Inc, 2008. p.35533554.

VESSONI PENNA, T.C. Validação de processos de esterilização: conceitos básicos Laes \& Haes. São Paulo, v.15, n88, p.4648, 1994.

VESSONI PENNA, T.C.; MACHOSHVILI, I.A. Esterilização térmica: conceitos básicos da cinética de morte microbiana. Rev. Farm. Bioquím., v.34, suppl.1, p.1-5, 1997. 
VITAL BRASIL INSTITUTE. Controle ambiental de área limpa do setor de esterilidade. Manual de controle da qualidade. In: VITAL BRASIL INSTITUTE. Normas Internas. Niterói: IVB, 2006a (IT n ${ }^{\circ}$ DCB.C: 013/MB). p.12-2.

VITAL BRASIL INSTITUTE. Informe didático. Publicação Interna. Niterói: Ed. Assessoria de Comunicação Social do IVB, 2006b. p.35-39.

VITAL BRASIL INSTITUTE. Teste de esterilidade de plasma por inoculação direta. In: VITAL BRASIL INSTITUTE. Manual de controle da qualidade. Normas Internas. Niterói: Ed. IVB, 2006c (IT n ${ }^{\circ}$ DCB.C: 078/MB). p.27-33
VITAL BRASIL INSTITUTE. Teste de esterilidade por filtração em membrana. In: VITAL BRASIL INSTITUTE. Manual de controle da qualidade. Normas Internas. Niterói: Ed. IVB, 2005 (IT n ${ }^{\circ}$ DCB.C: 028/MB). p.55-68.

WILSON, J. Parametric release. In: NORDHAUSER, F.M. and OLSON, N.P. Sterilization of drugs and devices: technologies for the 21st century. Buffalo Grove: Interpharm, 1998. Cap.14, p.487-515.

Received for publication on $1^{\text {st }}$ August 2007 Accepted for publication on $13^{\text {th }}$ January 2009 